\title{
A tribute to Paul A. Marks, MD, 1926-2020
}

0 n April 28, 2020, the world lost a giant of medicine: Dr. Paul Alan Marks, a pioneer in human genetics, the architect of the modern cancer center, and a former editor of this Journal (1967-1971) (Figure 1). Marks had humble beginnings in a coal town in rural Pennsylvania, born to Russian Jewish immigrants employed in the clothing industry. Raised by his grandparents in Brooklyn, Paul was taken under the wing of a high school teacher who had recently lost his physician son in the ongoing World War II; this teacher helped inspire Paul to a career in medicine. While at Columbia, Paul's fate was sealed, when - as chance would have it - his roommate was the future Nobel laureate Joshua Lederberg, who was already doing research on genetics and who "literally dragged [him] into the lab," as Paul told the JCI (1).

Now permanently hooked, Marks completed his MD degree and medical residency at Columbia before embarking on his research career, which began at the NIH as a postdoctoral fellow in the laboratory led by enzymologist and later Nobel laureate Arthur Kornberg. Returning to Columbia in 1955, Marks artfully combined enzymology and genetics with his clinical interest in hematology using the relatively simple red blood cell as a model. In what is now considered classic work, he soon discovered a genetic defect in the enzyme glucose-6-phosphate dehydrogenase (G6PD) as a cause of hemolytic anemia. He went on, in the 1960 s, to make the pivotal observation that defective messenger RNA for one of the subunits of hemoglobin is a cause of thalassemia. Then, in 1971, Charlotte Friend made the accidental and unexplained discovery that the simple solvent dimethyl sulfoxide (DMSO) caused an erythroleukemic cancer cell line to produce hemoglobin.

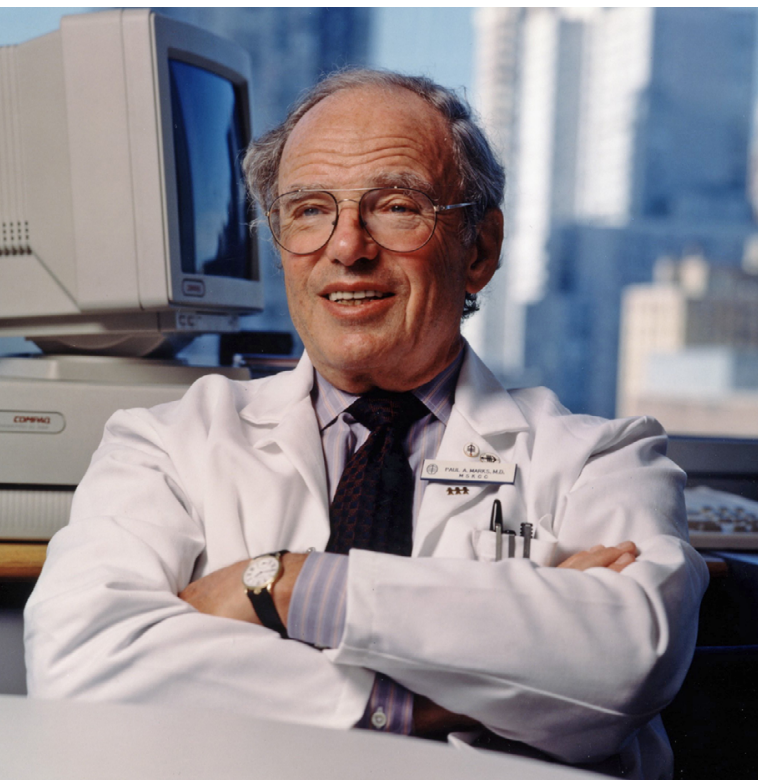

Figure 1. Paul A. Marks, MD, led Memorial Sloan Kettering Cancer Center from 1980-1999, during a period of dramatic transformaon for the institution.

in academia and in the biopharmaceutical industry.

Paul's early scientific contributions were recognized by his election to the US National Academy of Sciences in 1973, and his later and broader contributions were recognized by the National Medal of Science, presented to him by President George H.W. Bush in 1991.

Paul Marks was a man of great energy, ambition, and charisma; he was tall, with the gift of stunningly brilliant blue eyes and an infectious smile. He had an uncanny ability to spot and cultivate talent, and he was a remarkable and quick judge of character. While given to wry humor and radiating a natural warmth, he could also be formidable, pursuing important goals single-mindedly and practically, but ultimately unselfishly. For Paul, it was always about the institution,

Marks brilliantly seized on this serendipitous finding to found a new field. $\mathrm{He}$ surmised that the cancer phenotype could potentially be reversed - even when the cancer was caused by permeant mutational changes in the DNA sequences - by a totally novel kind of differentiation therapy that would epigenetically reset the developmental program to that of the normal cell. With his colleague and long-term research partner, the late Richard Rifkind, and the late Columbia chemist Ronald Breslow, Marks systematically and forcefully tested his idea, developing ever more potent analogues of DMSO, ultimately resulting in the 2006 FDA approval of the drug SAHA (vorinostat) for treatment of cutaneous $\mathrm{T}$ cell lymphoma. SAHA alters the pattern of gene transcription by acting on key enzymes that chemically remove acetyl groups from the histones that package DNA. This landmark body of work provided the proof of principle that drugs can successfully target epigenetic modifications to treat cancer, now a major goal not the individual. This extraordinary combination made him a natural leader. People from all walks of life were drawn to him, pulled in by the vortex resulting from his larger-than-life persona.

Thus, Paul did not go unnoticed. In the wake of the student disruptions of the late 1960s, famously begun at Berkeley and Columbia, the latter's medical school turned to Marks, then 44 years old, to be its next Dean, despite his young age and limited administrative experience. Marks attracted major talents to Columbia, including the future Nobel laureates Eric Kandel and Richard Axel, and provided strong leadership to its cancer center. When Axel (and Michael Wigler) discovered how to introduce DNA into cultured animal cells, broadly enabling molecular biology, Marks recognized the commercial potential in an era when it was not yet the custom to patent basic methodologies, ultimately fueling Columbia's growth with royalty streams exceeding $\$ 100$ million annually. Increasingly visible outside of the academy, Paul served on presidential panels for cancer and biomedical research. In 1979, President Carter called on Marks to provide expert advice as part of the 
President's Commission on the [Nuclear] Accident at Three Mile Island.

Marks' success at Columbia was noticed across town. In 1974, the SloanKettering Institute was torn by a very public research fraud scandal, causing a frank structural appraisal by its Board, which included the venture capital pioneer Benno Schmidt and Laurance Rockefeller, the Chair of the Board and long-time patron of Memorial SloanKettering (MSK). They knew that fundamental changes would be needed, and in 1980, Marks agreed to lead the rebuilding effort as President. Marks found an inbred culture, which he set about fixing by insisting on a uniform and high standard of excellence, whether for basic or clinical researchers, relying on external peer review by stars in the field. There had been no tenure system. Installing one provided Marks the catalyst and the means to effect systemic changes. This dramatic reshaping resulted in the globally influential concept of what a cancer center should be. However, getting there was not without controversy, as famously captured in a contemporaneous cover story in the New York Times Sunday Magazine. Within a decade, MSK Cancer Center (MSKCC) became the acknowledged world leader in cancer research, training, and treatment.

Paul Marks' impactful career at the intersection of science, medicine, business, and government occurred in the global epicenter of culture, New York City, where he touched many people from many walks of life. It seemed that everyone knew Paul Marks - and that he knew everyone. And not just scientists. In a typical visit to his office, our meeting would be interrupted by a call from the Clinton White House and, a few minutes later, from a US Senator. Then, a board member or family friend seeking medical advice. Later, a banker wanting Paul's opinion on a biotech product. Once, the Israeli Prime Minister called to say he was in town. All of this made Paul memorable, made his own life interesting, and also provided a springboard for the prodigious fund-raising that helped him to build the world's greatest cancer center.

Paul and his wife, Joan, a major figure in the field of genetic counseling, conducted MSKCC as an elegant extended family. They made us all feel a part of their home and life, and they shared their many and varied interests in music, art, and travel. In addition to Joan, Paul leaves three children - Andrew Marks, MD; Matthew Marks; and Elizabeth Ostrer - as well as six grandchildren and two great grandchildren.

I had the privilege of working with Paul at MSKCC from 1991 to late 1999, when he retired as President as the century ended. During that time, our family became part of his family, and it remains so. There are few, very few, people with whom virtually every encounter is etched in memory because it was somehow remarkable. I was privileged to have many singular moments with this great man. When he was recruiting me, I was offered a standard faculty office, about a third the size of my office at Princeton, and I balked. He paused and, only when the tension had peaked, said, "Okay Jim. We can do that. But from now on, you and I are going to have a relationship." He really meant it.

\section{James E. Rothman}

Address correspondence to: James E. Rothman, Department of Cell Biology, Yale University School of Medicine, 333 Cedar Street, New Haven, Connecticut, USA. Phone: 203.737.5293; Email: james. rothman@yale.edu.

1. Neill US. A conversation with Paul Marks. JClin Invest. 2012;122(10):3371-3372. 